\title{
腸炎菌感染についての実驗的研究
}

\section{X 線被照射動物における晹炎菌感染の增強}

\author{
山內信 \\ 日本医科大学衞生学教室 (指導 八田貞義教授)
}

[受付：11月 16 日 1954 年]

\section{まえがき}

大量X線の全身照射により宿主の抵抗が弱まり，感染 の成立が確実性を带びることは, 多くの研究者により報 告されている1-8)。Liu ら1は，X 線被照射マウスは発 疹チフス・リヶッチア Breinl 株腹腔内接種により, り ヶッチアによる高度の腹膜炎を起して死妨と述べ，Gowen ら2は遺伝的に抵抗を異にするマウス群にX線を照 射した後に鼡チフス菌を接種して，その際の生放率より マウスの抵抗がいずれの群に批いても，X線照射により 減少することを結論して抢る。Bond ら²) はX線照射が ラッテの肺疾患の蔓延の割合を増加させ，静止している 感染を活動化させることを示唆し, 中川らうはマウスの

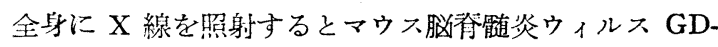
VII 株，並びに小児麻瘏ウィルス Lancing 株に対する 感受性は高まるとしている。Shechmeisteらタ)は，マウ スに潜伏している Pseudotuberculosis はX線照射によ り活動化され, 又 Corynebact. pseudotuberculosis 接

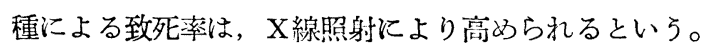

宿主のX線照射により, 菌力の低い微生物による感染

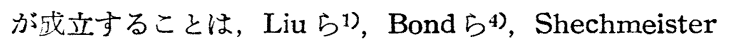
ら8)の報告の他に Miller ら99, Gonshery ら10) 及び

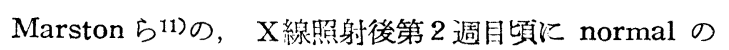
Darmflora による菌血症が出現するとの報告がある。

X線照射は一般に大量では宿主の感染に対する抵抗を 減弱させ，少量では抵抗を增強する19-16)とされて抢り， これは Arnedt-Schultz の法則17)に合致する。又 Trichina のような高等な寄生虫は，宿主の大量X線照射に よりその胎内発生か蹱害され, 宿主側としては治療効果 があると報告されている18-20)。

私はさきに腸炎菌の強毒株をマウス及びウサギに経口 投与した際の所見を報告した21)が，感染には宿主側の問 題として, 実験動物について種々の条件が検討されねね゙
ならない。著者は本実験に打いて，腸炎菌に対する感受 性を異にするマウス，モルモット，ウサギはX線照射に より全身の抵抗性を弱め, 攻撃菌による感染の成立が確 実性を帯びることを認めたので，その大要を報告する。

\section{実験 III. X線被照射マウスの腸炎菌経口感染}

実験方法 体重 11〜 $15 \mathrm{~g}$ のマウス 54 匹を 3 群に分け 20 匹ずつの 2 群に夫љ 300 r，150rを 3 日間に分割照射 し, 最後の照射より 5 日後に, 腸炎菌RG 3 株を実験 ${ }^{21}$ と同様の方法により経口投与した。残りの14匹は菌投与 のみの対照とした。

$\mathrm{X}$ 線照射は, 日本医大第一医院の深部治療用装置によ り, 同教室山中教授, 斎藤講師, 高橋学士その他の各位 の御援助を得て行なつた。照射条件は管電圧 $150 \mathrm{kV}$, 管 電流 $3 \mathrm{~mA}$, 滤過板 $\mathrm{Cu} 0.5 \mathrm{~mm}, \mathrm{Al} 1.0 \mathrm{~mm}$, 皮膚焦点 距離 $50 \mathrm{~cm}$ ，毎分 $\gamma$ 量 4.1 r とした。

実験成績：実験結果は第 1 表に示した。300r, 及び $150 r$ 照射群マウスは，菌を投与する以前に夫々 15 匹 及び 9 匹死んだ。菌投与 1 日後にはいずれの群のマウス も死なつい。1〜2 日後に殺した各群について臟器の培 養を行なつたところ，300 被照射マウスは150 r被照 射マウスよりる菌の体内分布が広く, $150 r$ 被照射マウス のそれは対照よりも広い。すなわち菌の侵襲性がX線照 射の前処置により強められることが知られた。逐日屠殺 の対照としなかつたマウスの菌投与後の整死日数は 300 r 150 照射及び無照射群につき，夫々 2〜6 日後，3〜 11 日後, 及び $6 \sim 13$ 日後であり，無照射群マウスでは 2 匹が 3 週間以上生残した。又X線被照射群の菌投与後

YAMAUCHI Makoto: Experimental Studies on the S. enteritidis Infection. II. Enhancement of S. enteritidis Infection in X-Irradiated Animals. Department of Hygiene, Nippon Medical School, Tokyo. - Jap. J. of Bact. 10(5), 451-458 1955. 
第 1 表 全身にX線を照射したマウスに腸炎菌 RG 3 株を攝苓させた際の成綪

\begin{tabular}{|c|c|c|c|c|c|c|c|c|c|c|c|}
\hline \multirow{2}{*}{ X線照射 } & \multirow{2}{*}{$\begin{array}{l}\text { 菌摄取後 } \\
\text { の日数 }\end{array}$} & \multicolumn{5}{|c|}{ 臟 } & \multicolumn{4}{|c|}{ 器 } & \multirow{2}{*}{$\begin{array}{l}\text { 菌摄取前 } \\
\text { の死亡数 }\end{array}$} \\
\hline & & 血 液 & 肝 & 脾 & 肺 & 呰 & \multicolumn{2}{|c|}{ 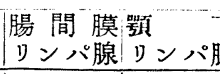 } & \multicolumn{2}{|c|}{$\begin{array}{l}\text { 下鼬 喛大 } \\
\text { 腺りンパ腺 }\end{array}$} & \\
\hline $25 / \mathrm{XI}$ & 1 & + & + & + & + & - & + & - & - & - & \multirow{5}{*}{15} \\
\hline $26 / \mathrm{XI}$ & $2(+)$ & + & $H$ & $H$ & + & + & $H$ & - & - & - & \\
\hline $27 / \mathrm{XI}$ & $2(+)$ & - & $H$ & $H$ & - & - & + & - & - & $H$ & \\
\hline \multirow{2}{*}{$300 r$} & $3(+)$ & - & - & $H$ & - & - & - & - & - & + & \\
\hline & $6(+)$ & + & $H$ & $H$ & $H$ & - & $H$ & $H$ & - & - & \\
\hline \multirow{7}{*}{$\begin{array}{l}25 / \mathrm{XI} \\
26 / \mathrm{XI} \\
27 / \mathrm{XI}\end{array}$} & 1 & - & - & $H$ & - & - & - & - & - & - & \multirow{11}{*}{9} \\
\hline & 2 & $H$ & $H$ & $H$ & $H$ & $H$ & H & - & - & + & \\
\hline & $3(+)$ & - & $H$ & + & + & - & - & + & + & $H$ & \\
\hline & $3(+)$ & $H$ & $H$ & $H$ & + & - & $H$ & - & - & $H$ & \\
\hline & $6(+)$ & $H$ & $H$ & $H$ & $H$ & $H$ & - & + & + & + & \\
\hline & $6(+)$ & + & + & $H$ & + & - & + & + & + & H & \\
\hline & $7(+)$ & $H$ & $H$ & $H$ & + & $H$ & $H$ & + & + & $H$ & \\
\hline \multirow[t]{4}{*}{$150 r$} & $9(+)$ & $H$ & $H$ & $H$ & $H$ & $H$ & $H$ & $H$ & $H$ & $H$ & \\
\hline & $9(+)$ & $H$ & H & $H$ & $H$ & - & $H$ & $H$ & - & $H$ & \\
\hline & $10(+)$ & $H$ & $H$ & $H$ & $H$ & $H$ & $H$ & $H$ & $H$. & $H$ & \\
\hline & $11(+)$ & $H$ & H & $H$ & $H$ & $H$ & $H$ & $H$ & - & - & \\
\hline \multirow{6}{*}{ 無 } & 1 & - & + & $H$ & - & - & - & - & - & $H$ & \multirow{14}{*}{0} \\
\hline & 2 & - & - & + & - & + & - & - & - & $H$ & \\
\hline & 3 & + & $H$ & $H$ & $H$ & - & - & $H$ & - & $H$ & \\
\hline & $6(+)$ & $H$ & $H$ & $H$ & $H$ & $H$ & $H$ & $H$ & $H$ & + & \\
\hline & $7(+)$ & $H$ & $H$ & $H$ & $H$ & $H$ & H & $H$ & - & $H$ & \\
\hline & $8(+)$ & $H$ & $H$ & $H$ & $H$ & $H$ & $H$ & t+ & $H$ & $H$ & \\
\hline \multirow{3}{*}{ 照 } & $10(+)$ & $H$ & H & $H$ & $H$ & $H$ & $H$ & $H$ & + & $H$ & \\
\hline & $11(+)$ & $H$ & $H$ & $H$ & $H$ & $H$ & $H$ & $H$ & $H$ & $H$ & \\
\hline & $11(+)$ & $H$ & $H$ & $H$ & $H$ & $H$ & - & - & - & $H$ & \\
\hline \multirow{5}{*}{ 射 } & $13(+)$ & $H$ & $H$ & $H$ & $H$ & $H$ & $H$ & $H$ & $H$ & + & \\
\hline & $13(+)$ & $H$ & $H$ & $H$ & $H$ & $H$ & $H$ & $H$ & + & + & \\
\hline & $13(+)$ & $H$ & $H$ & H. & $H$ & $H$ & - & $H$ & - & + & \\
\hline & 20 & - & - & - & - & - & - & - & - & - & \\
\hline & 20 & - & - & - & - & - & - & - & - & - & \\
\hline
\end{tabular}

X線照射条件一滤過板：Cu $0.5 \mathrm{~mm}, \mathrm{Af} 1.0 \mathrm{~mm}$; 管電压： $150 \mathrm{kv}$; 管電流： $3 \mathrm{~mA}$; 皮漕焦点距離 :

$50 \mathrm{~cm}$; 毎分 $\gamma$ 量 : $4.1 \gamma$.

菌投与： $2 / \mathrm{XII}$. 普通ブイョン 18 時間培養の 8 滴, $(+)$ : 擎死マウス

$\mathrm{H}$ : 直接平板塗抹により菌の検出されたもの, + ：增菌法により菌の検出されをもの,

一：菌の検出されなかつたもの

の擎死例の体内の菌の分布が，比較的濃厚でないことに より，体内菌増殖が高くなくても動物が死んだことが示 される。

総括及び考察 Chrom $^{22)}$ は, 或る種の菌血症 (二次敗 血症）に特有な血中菌の一時的の陰性期が450r 照射 72 時間後に Breslau bacillus を静脈内に注射されたマウ
スではみられないと報告しだ。私のマウスを用いた実験 で，無照射マウス菌投与 2 日後まで血中菌除性であつた のに対し，300r被照射マウスは菌投与 1 日後に血中菌 陽性であつたこと,ならびにX線被照射マウスが対照の 無照射 マウスより明らかに早期に死んでいることは, Chrom ら22) の認めた事実と共に, 普通の動物では二次 
敗血症となる条件においても，X線被照射動物では侵琵 性の増強のため一次敗血症が起り得ることを示するので ある。この考光方は，マウスにX線を全身照射すること によつて, 微量の菌の腹腔内接種によつても必ずマウス を感染整死せしめたとの, 牛場23)の所見とも一般する。 菌投与後に擎れたマウスの体内菌分布が，X線被照射群 に拐いて比較的濃厚でなかつたのは, 細菌感染と直接関 係のないX線自体による一次的障害が，この実験では充 分避けられていなかつたことが，その理由の一つとして 考穴られる。

\section{実験 IV.X線被照射モルモットの腸炎菌経口感染}

実験方法：体重 370 550g のモルモット5 匹の5 ち，3匹にX線を $200 r$ 全身照射し，4 日後に被照射動 物の 2 匹及び 無照射の 2 匹に, RG 3 株を経口投与し， 投与後18日間観察した。照射条件は管電圧 $160 \mathrm{kV}$ ，管電 流 $3 \mathrm{~mA}$, 濾過板 $\mathrm{Cu} 0.1 \mathrm{~mm}, \mathrm{~A} 11.0 \mathrm{~mm}$, 皮膚焦点距 離 $50 \mathrm{~cm}$, 毎分 $r$ 量 $6.2 \gamma$ とした。

菌投与は，普通寒天斜面 20 時面培養菌 3 öse をなめ とらせる方法によつた。

実験成績：第 1 困，第 2 表に示した。X線を照射さ れたモルモットは，菌投与 3 日後に $40^{\circ} \mathrm{C}$ 以上の体温上 昇を来し，いずれす体重が減少して 8 日後に死んだ。こ のちちはじめの体重 $550 \mathrm{~g}$ の No. 3 モルモットは肝, 脾及び腎に, $460 \mathrm{~g}$ No. 2 モルモットは血液, 肺, 肝, 脾，腸間膜・顎下及び単跨りンバ結節，並びに腎に投与 菌が検出され，少くとも後者は二次敗血症の像を呈した それに反し，菌摂取のみのモルモットはいずれも体温は $40^{\circ} \mathrm{C}$ 以上飞至らず，体重も恢復して 16 日以上生残し， 16 日後にその 1 匹を殺して蔵器の培養を行なつたとこ ろ, 脾, 腸間膜及び顎下りンパ結節に投与菌が検出され た。X線照射のみのモルモットは，照射14日後に体重低 下と $40^{\circ} \mathrm{C}$ 以上の体温上昇を示したが，1 カ月以上生存 した。

総括及び考察： 実駼 III では, X線の前処置を行わ ずして菌を投与した動物群に少数の生残例はあつたが, マウスはこの菌株に対する感受性が強く，且つX線の, 細菌感染とは直接関係のない一次的障害を完全に考えに 入れないわけにはゆかない実験条件であつた。そこで感 受性の比較的低いモルモットを用い，X線照射のみの対 照も置いて実験を行なつたところ，X線前処置を行なつ た群と然らざるるのとの間に明確な差異が認められ，菌 の侵慜に対する抵抗が，X線照射によつて明らかに低下 することが観察された，そして菌投与のみのモルモット の脾及び，晹間膜並びに顎下リンバ結節に菌が検出され
第1 図 モルモットに $200 \gamma$ 全身照射し腸炎菌;RG 3 株を経口投与した際の所見
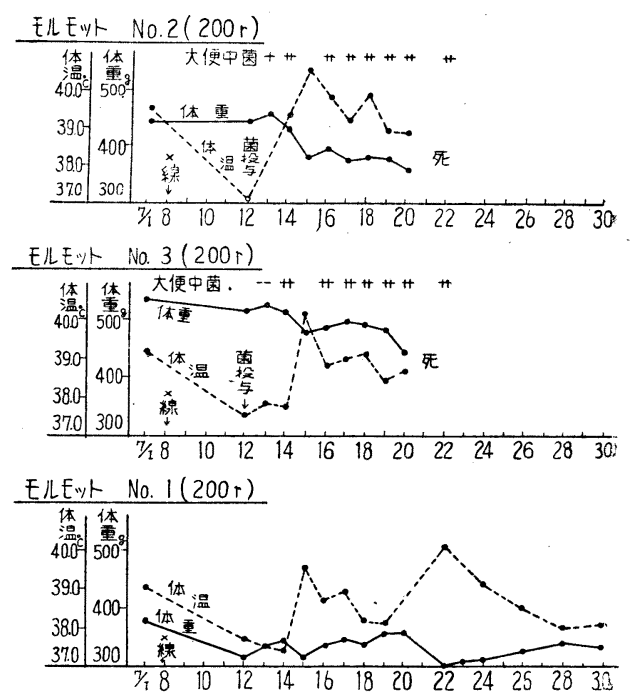

EルEット No.4.(無 照 射)

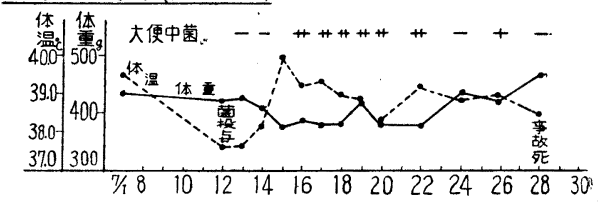

EルEッ卜 No.5 (無 照射)

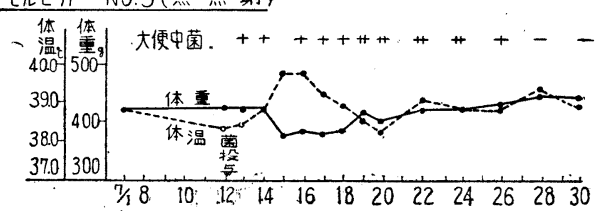

$\mathrm{X}$ 線照射条件一㴓過板 : $\mathrm{Cu} 0.1 \mathrm{~mm}, \mathrm{AL} 1.0 \mathrm{~mm}$; 管電压 : $160 \mathrm{kV}$; 管電流 : $3 \mathrm{~mA}$; 皮有照点距離 : $50 \mathrm{~cm}$ ：每分 $\gamma$ 量: $6.2 \gamma$. 菌投与: 普通寒天斜面 18 時間培養菌の 3 öse.

たことからいつて,この実験では，X線照射による感染性 の変動は肯定されなかつた。文 Orskov ら24) のいう， 菌が当然はじめに通過しなければならないと考兄られる リンバ結節への, 菌の抑留はNNo.4モルモットに执いて 明確にみられ，従つて Orskov らの所論は，菌の質的 或は量的条件，及び動物の条件が或る範团内にあるとき には全く正しいといえよう。

X線照射のみのモルモットが，照射 14 日後に体温上 昇と体重低下とを示したのは，血液の培養を行わなかつ たから断定はできないが, 腸内常在菌による菌血症 ${ }^{9-10)}$ であつたのかもしれない。

実験 V. X線被照射ウサギの腸炎菌経口感染 
第 2 表 腸炎菌投与モルモット贜器よりの菌検出成綪

\begin{tabular}{|c|c|c|c|c|c|c|c|c|c|}
\hline & & & & & & & 腸間膜 & 敫下 & 鼠蹊 \\
\hline $\begin{array}{l}\text { 動 } \\
\text { 番 号 }\end{array}$ & 解剖 & 血液 & 肺 & 肝 & 脾 & 腎 & \begin{tabular}{|l} 
リンパ \\
腺
\end{tabular} & $\begin{array}{l}1 ン \\
\text { パ腺 }\end{array}$ & $\begin{array}{l}1 ン 2 \\
\text { パ腺 }\end{array}$ \\
\hline 2 & $2 / 1$ & $H$ & $H$ & $H$ & $H$ & $H$ & + & $H$ & $H$ \\
\hline 3 & $22 / I$ & - & $H$ & $H$ & $t+$ & + & - & - & - \\
\hline 4 & $30 / /$ & - & - & - & $H$ & - & $H$ & $H$ & - \\
\hline
\end{tabular}

$H$ : 直接平板塗抹により検出, + : 增菌法により検出

実験方法：X線照射は上半身，全身，灭び下半身の 三条件について行なつた。上半躬照射は，胸骨剣状突起 より尾側を含鉛ゴム板で覆い，12日間に 6 回に分けて総 量 $1850 r$ 照射した。全身照射は:1050rを14日間に10回 飞分けて照射した。いずれの場合にもウギは固定器に仰 臥位に固定して照射された。照射条件は管電圧 $150 \mathrm{kV}$, 管電流 $3 \mathrm{~mA}$, 滤過板 $\mathrm{Cu} 0.5 \mathrm{~mm}, \mathrm{Al} 1.0 \mathrm{~mm}$, Tubusな 乙, 皮膚焦点距離 $30 \mathrm{~cm}$ (上半身) 又は $50 \mathrm{~cm}$ (全身)， 毎分 $\gamma$ 量 11.4 (上半身) 及支び $4.1 \gamma$ (全身) とした。

ウサギは体重 1500 2500 g のものを用い，菌投与は RG 3 株の普通ブイヨン 18 時間培養液 $70 \mathrm{cc}$ を遠心によ り $10 \mathrm{cc}$ に濃縮したものを 1 匹分とし，パンに侵して摄 食させた。この材料中の菌数は約 700 億個であり, 実験 I 友びIII のマウスに抢㚈る投与量と, 体重 $\mathrm{kg}$ 当りほ 、将等量である。

実験成績：ウサギの体重は第 2 図に示すよ 5 に, 上 半身X線照射により $300 \mathrm{~g}$ ，全身照射により $400 \mathrm{~g}$ 減少し た。流血中白血球数は上半身照射により $2300 / \mathrm{mm}^{3}$, 全 身照射により $750 / \mathrm{mm}^{3}$ をで減少したが，菌投与の日に は 200 2500/ $/ \mathrm{mm}^{3}$ であつた。

菌投与のみの対照ウサギのうち，菌投与時の体重 1500 g であつた No. 6 ウサギは， 13 日後に整死したが，剖 検培養したところ肝，脾，腎，肺，腸間膜りンパ結節， 腹腔液，及び大便に投与菌が検出され，血中には菌は陰 性であつた。そして大網膜及び腸間膜に，夫及胡桃大及 び示指頭大の内容充実した腫瘍があり，死因はこの腫瘤 とも関係があるように思われた。

菌投与後の体重変動は，X線被照射動物と無照射動物 との間に認むべき差を示さず，体温は全身照射ウサギで は菌投与 6 日後に $40^{\circ} \mathrm{C}$ 以上であつた。

実験II21! に打いて，腸炎菌投与によりウサギの流血中 白血球数は $6 〜 8$ 日後に増加することが認められたが, この実験でも，菌投与 8 日後の白血球数は無照射ウサギ では夫々 $12,000 / \mathrm{mm}^{3}$ 及び $20,500 / \mathrm{mm}^{3}$ であつた。そ れに反し，上半身 X線照射の前処置を行つたウサギの白 血球数は，菌投与 4 日後に $10,000 / \mathrm{mm}^{3}$ を喼めたのみで
第 2 図 ウサギの上牛身又は全身に $X$ 線を照射し 腸炎菌 RG 3 株を攝畣させた際の所見

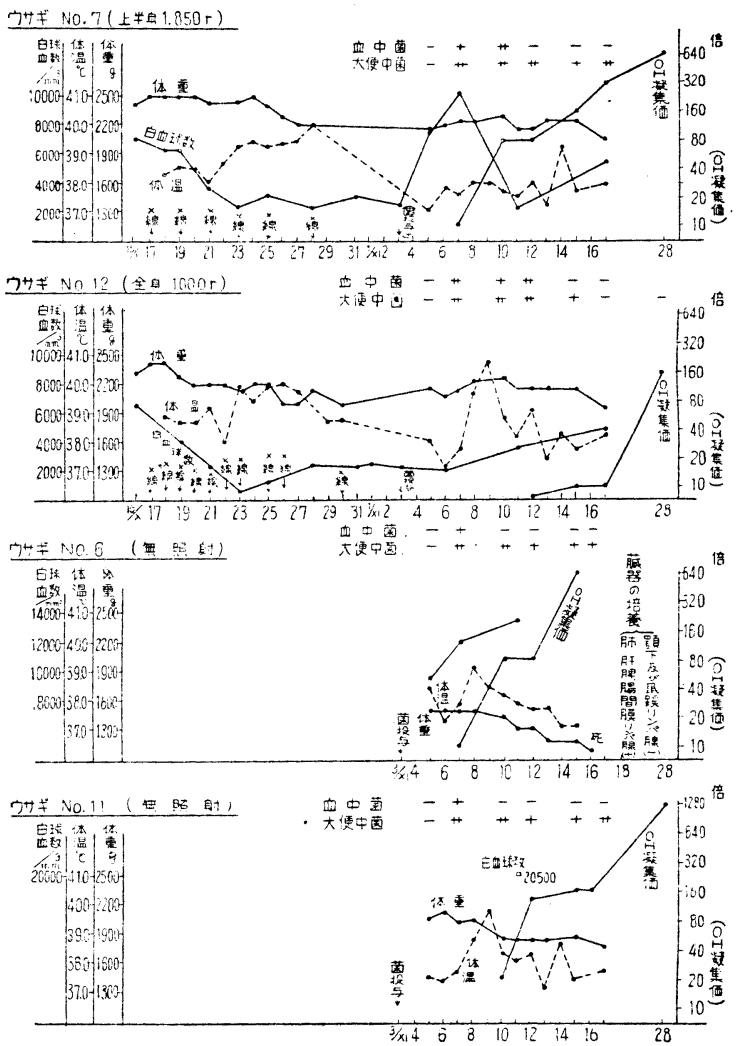

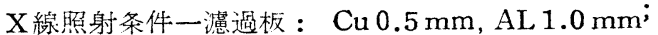
管電圧 $150 \mathrm{kV}$; 管電流 $3 \mathrm{~mA}$; 皮清照点距離; $30 \mathrm{~cm}$ (No. 7)，50 cm (No. 12); 毎分 $\gamma$ 量: $11.4 \gamma$ (No. 7), 4.15 (No. 12).

菌投与： 普通ブイョン 18 時間培羪の $70 \mathrm{cc}$ (遠心 により $10 \mathrm{cc}$ に濃縮）

全身被照射ウサギでは 14 日間の観察期間中に $5000 / \mathrm{mm}^{3}$ 以上の白血球数を認めなからた。

菌投与 $4,7,9,12,14$ 及び 25 日後汇 血清の $\mathrm{OH}$ 凝集素価を測定したところ，X線被照射動物，殊飞全身 被照射ウサギでは，無照射ウサギに比べて，血清の㠜集 素価が著るしく低かつた。

投与菌の血中への出現は，上半身及び全身X線被照射 ウサギでは 4〜 7 及び 4〜9 日後に陽性であり，無照射 ウサギでは 4 日後のみ陽性であつた。そして両者の間に は血中の菌数にも差異があると思われる所見があつた。

下半身にX線を照射されたウサギの実験成績は第 3 図 及び第 3 表のと拉りで，被照射ウサギは菌投与後 5 日後 
第 3 図 ウサギの下半身にX線を照射し腸炎菌 RG 3 株を攝食させた際の所見
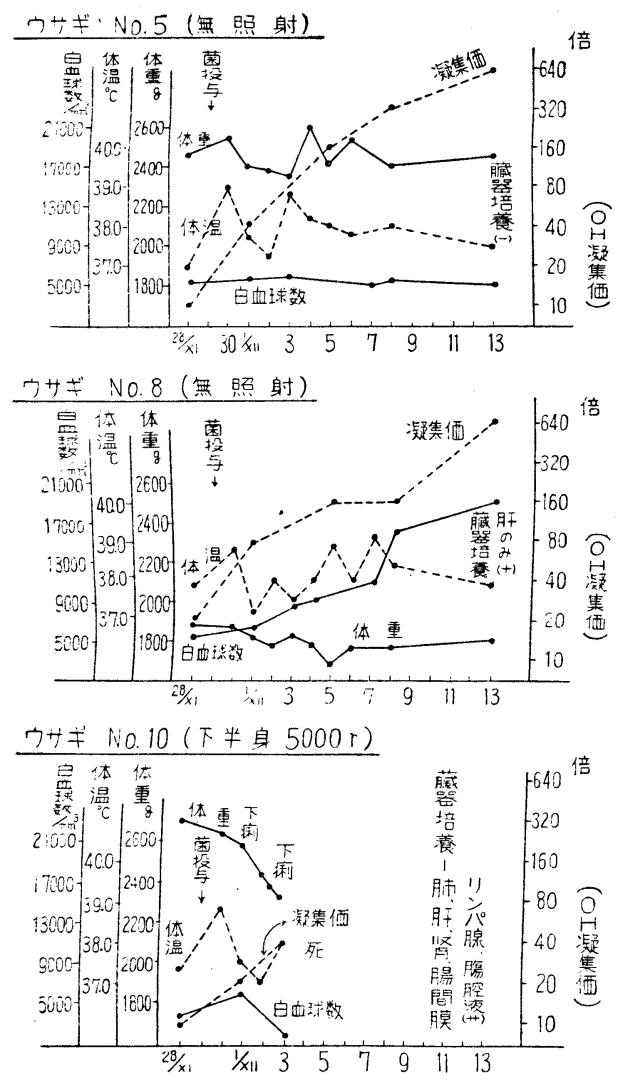

$\mathrm{X}$ 線照射; 22/XI

飞重篤な菌血症と下淿とを呈して擎れ，白血球特にリン ハ球の甚だしい減少がみられた。

総括及び考察：この実験に用いた動物の，腸炎菌に 対する感受性は, マウス>モルモット>ウサギの順でめ る。私の実験においてみられた $\mathrm{X}$ 線の腸炎菌感染に与兄 た变化は，マウスでは二次敗血症の一次敗血症への移行 であり，モルモットでは致死的感染，或は二次敗血应の 誘発であり，そしてウサギでは血中菌陽性期の延長と抗 体生成の抑制, 更に下半身大量照射では下㰾及び菌血症 と死であつた。これはX線照射により障害される25-2:)リ ンバ組織, 肝, 脾などの網内系の, サルモネラによるチ フス性疾患において演ずる役割を寒付けるるのであり, 動物種による先天的抵抗の差異が或程度定量的のるので あることを示している。

上半身被照射ウサギのX線による障害が, 全身被照射 ウサギの受けた障害に比べて，X線量が多かつたにも拘 らず低かつたことは，菌投与の方法が経口投与であつた
ことも関保があるか子知れないが，羊赤血球による免度 の前日に $800 \mathrm{r}$ 照射した際，脾或は虫垂が鉛の盾で防禦 されたウサギでは, 溶血素生成は単に遅れたのみであっ たという Jacobson ら28-29)の報告からも考えるように, 感染或は免疫に関して重要な意義を有する器官の多くが 横隔膜よりる尾側にあることを示唆する。下半身に 5,0 $00 r$ 照射後腸炎菌を投与されたウサギは; 整死後剖検し たところ, 腸管壁が薄くて機㭜的にも弱く, 脾は暗褐灰 色を呈して光沢を欠き，大きさる明らかに小さからた。

$\mathrm{X}$ 線照射後の宿主の, 感染に対する抵抗減弱文免度 低下の説明として, Gowen ら²) は鼡チフス菌感染のX 線照射による増強機転を，流血中の白血球数と関係ずけ て論じ, Taliaferro ら ${ }^{13.30 .31)}$ は大量X線照射によるり ンパ球，及び血液母細胞の破填が，或る重要な Mesenchymal reserve 飞影響を及ぼして, 網内系の食菌或は 抗体生成能を低下させると説き，X線により微生物自体 の毒力が増強されるとか，抗原性が破壊されるとかの証 拠はないと述べた。White 及び Dougherty ${ }^{32-333}$ は， X 線の抗体上昇に及ぼす作用を, リンパ球の生成作用に対 する pituitary-adrenal cortical control の概念により 説明しようとした。Clemmesen ら ${ }^{34)}$ は，600r X線被照 射ウサギに执いて，Salmonella paratyphi B に対する 抗体生成が低いこと〉, 被照射動物ではトリパン・ブルー 又は細菌の血中よりの消失が抢そいことから, 網内系の 障害に意義をるとめ, Burrow ら ${ }^{13)}$ は Cholera vibrio によるモルモットの胃内感染について実験し，X線照射 後の Coproantibody の低下は, 菌の体内への慕延と関

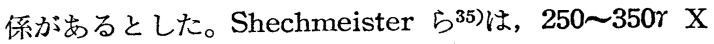
線照射 8 時間後のマウスに, 腸炎菌腹腔内接種による感 染に対する感受性の著るしい増加を認め, 照射後 8 時間 にはマウスの血中に顆粒細胞增加がみられたことから， X線によるこの抵抗減弱は，顆粒細胞減少によつては説 明され得ないとし, 大腸菌腹腔内接喠に対す。感受性の 増加は 1 日後にみられ, Str. zooepidemicusによる吸入 感染では, X線による感染の増加は照射 11 日後にみとめ た。放射線の侵襲性増強作用は感染性汶する变化より 早期汇現われ, 又侵裂性の増強がみられるのは, 強毒菌と 弱毒菌とではや〉異ることがこの実験により示されてい る。X線により宿主の細菌毒素に対する抵抗が減弱する ことに゙ついては, Adler 5 ${ }^{36)}$ 皮び Siverman ら37)のC1. septicum 及び Past. pestis に関しての報告がある。 Fränkel ${ }^{38)}$ は, モルモットは2〜2.4 SED照射により補体 の明らかな変化を示さないが，12.5 SED では顕著な低 下を示す事を羿め, Antonioli ${ }^{39)}$ はブドウ球菌に対する 
第 3 表 ウサギの下半身に $\mathrm{X}$ 線を照射し腸炎菌 RG 3 株を攝全させた際の所見

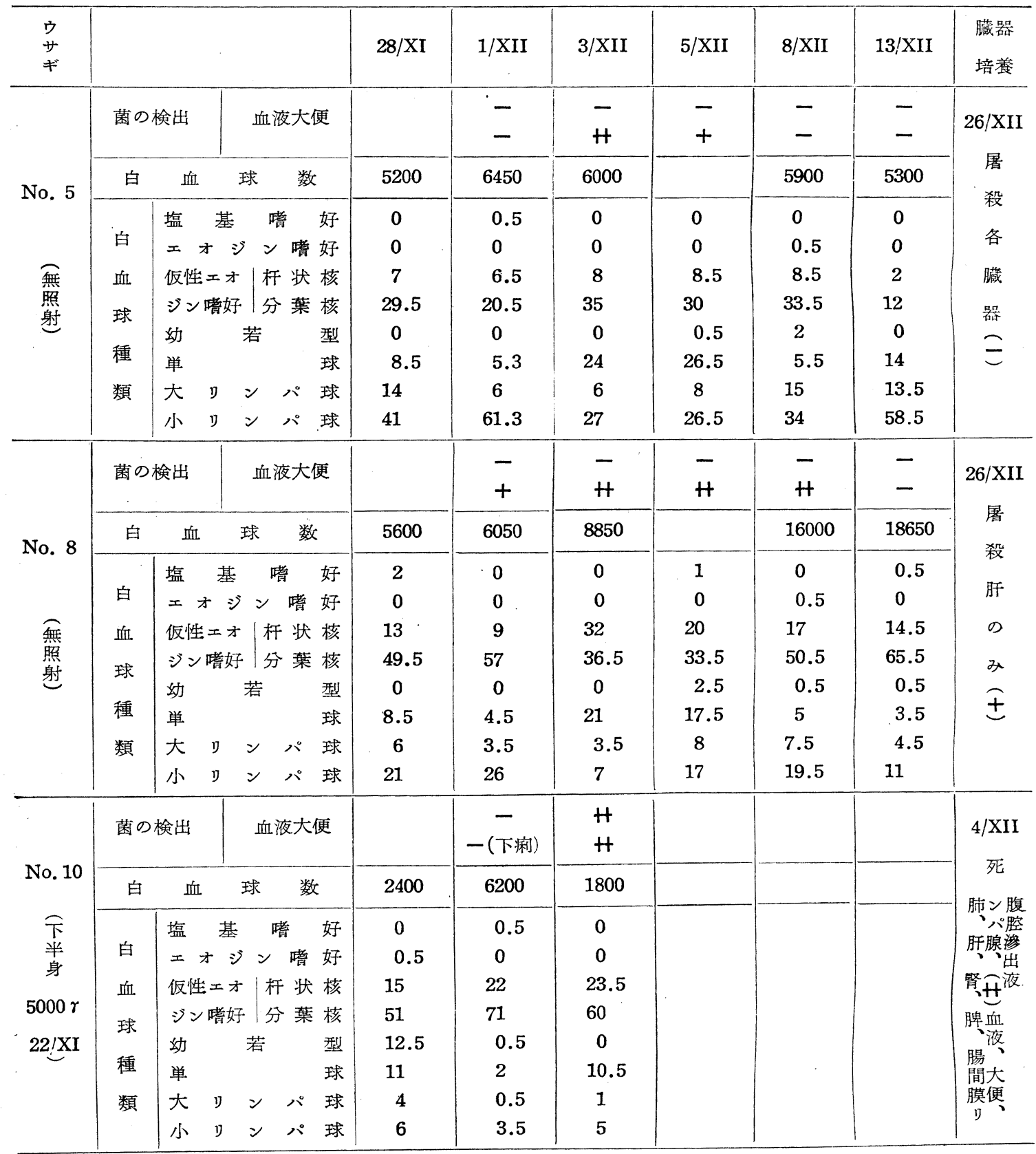

菌投与： $29 / \mathrm{XI}$. 普通ブイヨン 18 時間培養 $70 \mathrm{cc}$ を遠心により $10 \mathrm{cc}$ に濃縮したもの

種々の組織の試験管内殺菌力が， 750～1200r の分割照 射により減少したことを，網内系の変化によるとなした Marcus ら 40)は 650〜725r の全身照射により，ウサギ 血清の殺菌力が, 照射 1 日後には正常であるが 5 日後に 低下し，20日後には恢復していたと述べている。私の実
験により具体的に示されたことは，宿主のX線照射が腸 炎菌経口感染に際しその侵裂性を堌強し，抗体生成を抑 制したことであり，感染性の一因子と考えられる投与法 の腸管内増殖促進は，大便よりの菌の検出状況から考元 て肯定されなかつた。放射線の生体に対する作用本態は 
勿論その ionizing effect であろらが，この作用は生体 組織の全機能と関連しているので, 詳細な解明は困難で ある。しかし, いかなる感染促進, 或は毒力増強手段と いえども，実験者の予期しないような影響を生体に与え ないものはなく, 感染免疫現象に関し, 放射線は他の手 段によつては生起できないような変化を宿主に与えるこ とができるので, 感染論特に二次敗血症の本態, 生菌免 疫に括ける組織免疫の分析研究などには，有力な手段と なるであろう。

\section{結論}

X線は照射したマウス，モルモット及びウサギに，照 射数日後に腸炎菌強毒株を経口投与し, 侵裂性の增加と 抗体生成の抑制とを認めた。

$300 r, 150 r$ 被照射マウスに腸炎菌強毒株を摄食させ ると, 菌は $1 \sim 2$ 日後に血中に現われ，マウスの整死時 期は無照射の対照に比べて早くなる。X線被照射マウス の䁍器に打ける投与群の分布は, 濃厚でないるのが認め られた。

$200 r$ 照射モルモットでは，腸炎藩による感染発症が 顕著で，10日後にはいずれる死に，2匹中 1 匹は明らか に二次敗血症であつた。

1,050 又は $1,850 r$ を夫及全身入は上半身に照射し たウサギに，腸炎菌を経口したところ，血中に投与菌の 検出される時期は，無照射の対照ウサギにおけるより長 かつた。血清中 $\mathrm{OH}$ 凝集素の生成は，全身被照射ウサギ では甚だしく抑制された。下半身に 5,000 万照射された ウサギに腸炎菌を投与したところ, ウサギは菌血症と下 利とを呈して，5 日後に死んだ。

以上の所見より考察されることは, X線照射は, 感染 論, 二次敗血症, 或は生菌免疫に拈ける組織免疫の分析 のための手段を支えうるようである。

\section{文献}

1) Liu, P. J., Snyder, J. C. and Enders, T. F.: J. Exper. Med. $73: 669 \sim 671,1941$.

2) Gowen, J. W. and Zelle. M. R. : J. Infect. Dis. 77 : 85 91, 1945.

3) Bentler, H. and Gazon, H. M. : J. Immunol. $68: 227 \sim 242,1952$.

4) Bond, V.P ., Shechmeister, I. L.,Swift, M. N. and Fisher, M. C. : J. Infect. Dis. 91 : 26 32, 1952.

5) Kaplen, H. S., Speck, P. S. and Gawetz, E.: J. Lab. and Clin. Med. $40: 682 \sim 691$, 1952.

6) Shechmeister, I. L., Bond, V. P. and Swift, M. N.: J. Immunol. $68: 87 \sim 95,1952$.

7) 中川, 神田, 大隈 : 日本細菌学雑誌, $8: 891$
昭 28 (1953).

8) Shechmeister, I. L. and Adler, F. L.: J. Infect. Dis $92: 228 \sim 239,1953$.

9) Miller, C. P., Hammond, C. W. and Tompkins, M.: Science, $111: 540 \sim 541,7.18 \sim$ 720, 1950; J .Lab. and Clin. Med. $83: 331$ $\sim 343,1951$.

10) Gonshery, L. Marston, R. Q. and Smith, W. W.: Am. J. Physiol. 172 : 359 364, 1953.

11) Marston, R. Q., Gonshery, L., Alderman, I. M. and Smith, W. W. : Am. J. Physiol. $172: 365 \sim 371,1953$.

12) 古屋: 日医大誌, $16: 80 \sim 86$, 昭 $24(1949)$.

13) Burrows, W. Deupree, N. G. and Moore, D. E. : J. Infect. Dis, $87: 158 \sim 168,1950$.

14) 藤浪: 医学通信, $5:$ （205） 4 6, 昭25(1 950).

15) Taliaferro, W. H. and Taliaferro, L. G.: J. Immunol. $66: 181 \sim 212,1951$.

16）古賀：日本医事新報, $1450 ： 463 \sim 468$, 昭 27 (1952).

17) Hoffmann, P.: Arch. Hyg. Bact. 91 : 1922

18) Semerad, J. E.: Am. J. Roentgenol. 38 : 470 477. 1937.

19) Evans, T. C., Levin: A. J. and Sulkin, N. M. : Proc. Soc. Exper. Biol. and Med. 48: 624 628, 1941.

20) Levin, A. J. and Evans, T. C. : J. Parasitol $28: 477 \sim 483,1942$.

21) 山内：日本細菌学雑誌 $10,245,1955$.

22) Chrom, S. A.: Acta Radiologica, 16 : 641 $\sim 660,1935$.

23）牛場：日本医事新報, $1575 ： 10 \sim 13$, 昭 29 (1954).

24) Orskov. A. and Moltke, O. . Z. f. Immunitätsf. 59 : 357 409, 1928.

25) 都筑：日本外科学会誌, $27: 253$, 大 15 (19 26).

26) 白木：治療及び处方, $19: 221,44$, 昭 13 (1938).

27) Bloom, W.: Histopathology Irradiation from External and Internal Sources. Mc Graw-Hill Book Co., New York, 1948.

28) Jacobson, L. O., Robson, M. E., Marks, E. K. and Goldman, M. C.: J. Lab. dnd Clin. Med. 34 : 1612 1613, 1949.

29) Jacobson, L. O., Robson, M. J. and Marks, E. K.: Proc. Soc. Exper. Biol. Med. 75 : 145 152, 1950.

30) Taliaferro, W. H. and Bloom, W.: J. Infect. Dis. 77 : 109 138, 1945.

31) Taliaferro, W. H., Taliaferro, L. G. and Simmons, E. L.: J. Infect. Dis. 77 : 158 $171,1945$. 
32) White, A. and Dougherty, T. F.: Fed. Proc. 4 : 109, 1945.

33) Dougherty, T. F. and White, A. : Endocrinology, 39, 370 385, 1946.

34) Clemmeson, J. and Anderson, E.K. : Acta Path. et Microbiol. Scand. $25: 611 \sim 614$, 1948.

35) Shechmeister, I. L., Paulissen, L.J. and Fishman, M.: Proc. Soc. Exper. Biol. Med. 83 : 205 209, 1953.

36) Adler, F. L. and Sechmeister, I. L.: Proc.
Soc. Exper. Biol. Med. 80 : 660 664, 1952.

37) Silverman, M. S., Chin, P. H., Greenman, V. and Young, J. C. : J. Infect. Dis. 94 : 47 52, 1954.

38) Fränkel, E.: Berl. Klin. Wchnschr. 49 : 2030 2032, 1912.

39) Antonioli, G. M.: Strahlentherapie, 41 : 496 501, 1931.

40) Marcus, S. and Donaldson, D. M.: Proc. Soc. Exper. Biol. and Med. 83 : 184 187, 1953. 